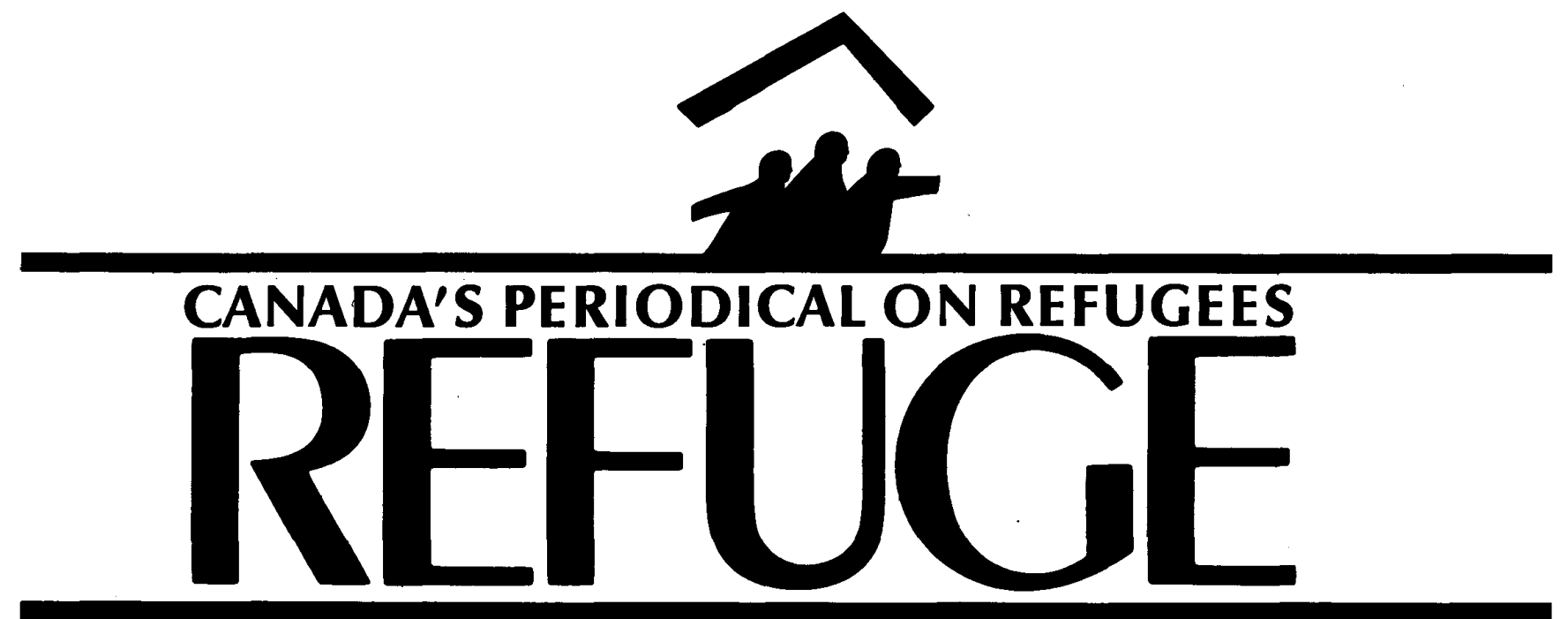

Vol. 2, No. 3

February, 1983

\title{
A Letter from the Jungle of Mexico a Few Hundred Yards from the Guatemalan Border. November 27, 1982.
}

The following dramatic account of conditions in a refugee camp in Mexico was received from a representative of an international organization working in that country.

Friends:

I was totally unprepared for what I found when I went to the refugee encampment in the Mexican jungle a few hundred yards from the Guatemalan border, where nearly 5,000 Mayan Indian men, women, and children have crossed some imaginary line thinking they would find shelter and safety.

In Guatemala, they face an active campaign of genocide. In Mexico, there are doctors, but they do not have medicine to treat the epidemics that rage. Nor cotton, alcohol, or soap. In this past week, at just this camp, the two intern doctors estimate 100 deaths. The newly improvised cemetery has about 30 graves, and the rest are buried near the small gatherings of nylon-tarp shelters.

The cause of death may be malaria, or tuberculosis, or diarrhea or whatever. Nothing is recorded. But the real cause is hunger.

This encampment is one of an estimated 25,000 in this jungle region. All the refugees are survivors of massacres. Their accounts are vivid and clear. After the massacres, they tried to hide in the mountains, but after watching their children die one by one, some tried to find their way to Mexico. Sometimes they travelled for 15 nights, hiding, unable to cook for fear their campfires would betray them.

Then, like the 86 who were sitting outside the hut in which I was sleeping, they arrive in the encampments. Their feet are blistered and torn. They have their few possessions on their backs - a few pots, maybe a blanket, whatever they could salvage. Even four-year-old children are carrying something on their backs, their heads bent down with the weight of the tumplines. There they sat until 4 p.m., without water or food.

Their arms are so thin. Yet everywhere one walks, there are smiles. Buenos dias!' Buenas tardes!' How can they maintain that harmony in the face of what is happening?

(Continued on p. 2)
ALSO FEATURED IN THIS ISSUE $\ldots \ldots \ldots \ldots \ldots \ldots \ldots$

CANADIAN REFUGEE POLICY, $1983 \ldots \ldots \ldots \ldots \ldots \ldots \ldots \ldots \ldots$

RECENT RESETTLEMENT OF SOUTHEAST ASIAN REFUGEES IN FRANCE

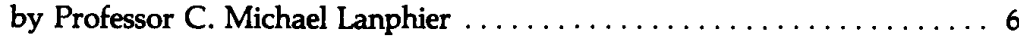


REFUGE

c/o Refugee Documentation Project,

York University, 4700 Keele Street,

Downsview, Ontario M3J $2 R 6$

Editor:

Howard Adelman

Managing Editor:

Caroline Stephens

Editorial Board:

Douglas Cohen, Montreal

Claudio Duran, Toronto

Arie van Eek, Burlington

Donald Ferguson, Toronto

James Hathaway, Moncton

Michael Pitman, Toronto

Linda Weigl, Regina

Typesetting and Layout:

Seagull Graphics Inc.

Refuge is dedicated to encouraging assistance to refugees, by providing a forum for sharing information and opinion on Canadian and international issues pertaining to refugees. It is published five times a year, in October, December, February, April and June. It is a non-profit, independent periodical supported by grants from the Canadian Foundation for Refugees, Operation Lifeline, and the Canada Employment and Immigration Commission; by private donations; and by subscription payments of $\$ 10$ a year. It is a forum for discussion, and the views expressed do not necessarily reflect those of its funders, staff or Editorial Board.

All material in Refuge may be reproduced without permission unless copyrighted or otherwise indicated. Credit should be given to the author or source if named.

Logo design:

Dreadnaught Cooperative Inc., Toronto

Second Class Mail Registration No. 5512 ISSNO229-5113

\section{Letters}

\section{To the Editor:}

Dear Sir:

Your "Newsflash" in the September/ October issue of "Refuge" stated: "The UNHCR has cancelled its agreement of co-operation with the Canadian Foundation for Refugees".

While it is true that the UNHCR and the CFR are no longer parties to a written agreement which made them partners in the areas of fund-raising and public education, it is wrong to say that UNHCR no longer has an agreement to co-operate with the CFR.

The Statute of the UNHCR provides that the High Commissioner may establish "contact in such manner as he may think best with private organizations dealing with refugee questions". We shall continue to provide the CFR with the best advice and support we can offer in
A Letter from the Jungle

(Continued from p. 1)

The centre Zunil has $\mathbf{3 2}$ families. There is only one infant under one year of age, and only 23 children under 5 . The rest did not survive.

No one can say exactly what is the food ration in the camp, because it seems to depend on the whim of the officials. But a family, say 6 persons, receives about 9 kilos of corn every 10 days, approximately. And one kilo of beans. Perhaps a bit of salt.

Understand that these refugees are virtually prisoners. To the south is the Guatemalan border and the Army. To the north is the Rio Lacuntun and hundreds of miles of jungle, accessible only by foot in the rugged terrain. In a few spots there are dirt landing strips. I arrived in a well-used Cessna, squatting on the floor behind the pilot, as the plane bounced into the air and continued at times just above the tree-covered mountains. Then, the clearings the refugees had made, looking like garbage dumps or debris from the tightly-packed black plastic roofs and downed trees and slash. We banked steeply, and hit the strip which the refugees themslves had constructed just days before. The flight cost for four persons: 6100 pesos, or something less than $\$ 100$. Supplies can arrive by launch, first by truck to Palenque, then an 11-hour trip by launch pro-

matters of mutual concern, as we do for all other voluntary agencies working in this sector.

\section{Yours sincerely, Itshaq $\mathrm{H}$. Brown \\ Representative in Canada of the United Nations \\ High Commissioner for Refugees \\ Our newsflash said the UNHCR cancelled its "agreement of co-operation" and not any informal} arrangements to co-operate. Ed.

\section{Editor's Note:}

Refuge would like to publish more articles by individuals working in the field. However, we have experience some difficulties in obtaining such articles. Following is a quote from a letter sent by one such individual:

'Unfortunately I cannot help you in your request for an article for Refuge magazine. A number of individuals and agencies here have gotten into big pelled by a 50 -hp motor. The logistics alone are overwhelming, not to mention the costs.

This is a difficult time to accomplish much in official Mexico. In just four more days, a new president will take office. What his policies will be, who his cabinet will be, no one knows. In the meantime, in this vacuum, particularly in these isolated areas, everyone is his own boss.

What needs to be done? Each person needs to find some way to exercise his or her human responsibility. There is a need for international commissions of investigation and periodic inspection of the refugee camps. International and diplomatic pressure are required so that Mexico will permit responsible international organizations to provide aid to the refugees. The international press should take note of the situation. Surely the media can manage to send reporters and cameras to the area.

Calls of concern should reach the Mexican Embassies. Write a letter of concern to Miguel de la Madrid, President of Mexico, Mexico City, urging that Mexico allow a non-governmental response to the refugee situation.

I hope that these words will convey to you the desperate plight of these dispossessed people.

Source: $A$ responsible representative of an international organization working in Mexico.

trouble by writing for external magazines. I feel my first obligation is to the program here. Therefore, I must refuse. I would really like to help you though. I thought of writing a few thoughts down, perhaps anonymously. I feel this is doing the same thing as writing some sort of article so I must refuse totally."

The Third International Conference on Soviet Jewry will be held in Jerusalem, March 15-18, 1983. The Presidium of the World Conference on Soviet Jewry called for the conference in response to the deteriorated situation of Jews in the Soviet Union. Further information may be obtained by writing to the Canadian Committee for Soviet Jewry, 212 Dunvegan Road, Toronto, Ontario M5P 2 P2. (416) 489-7133. 